\title{
Karst Types and Their Karstification
}

\author{
Márton Veress (i)* \\ Department of Geography, Eötvös Lóránd University, Szombathely-9700, Hungary \\ (iD) Márton Veress: https://orcid.org/0000-0003-4718-4225
}

\begin{abstract}
Eighty-one karst types and their main characteristics are described in this study, including the conditions of their development, the main characteristics of their karstification and their characteristic features. The classification includes the karst types of the Earth, a concise description of each karst type and the possibilities of belonging to several types of various karst areas. The classification of types is hierarchical in terms of groups, subgroups, types and subtypes. Karst can be classified according to their momentary state (the group of static karst types) and to their development (group of dynamic karst types). The group of static karst types has the azonal and zonal subgroups. Azonal karst types may be situated under any climate. These karst types are categorized according to their geological characteristics (age of karstification, constituting rock, extent of coveredness, structure), their elevation, expansion, the morphology of their surface, hydrology and to the effects occurring on the karst. Taking the above mentioned factors into consideration, the author distinguishes various types and describes their characteristics. Zonal karst types are also described (tundra karst, temperate karst, subtropical karst, tropical karst), karst types that can be distinguished based on their geomorphic evolution are identified and their characteristics are presented.
\end{abstract}

KEY WORDS: karst, karst type, classification of karsts, characteristics of karst type, azonal karst type, zonal karst type.

\section{INTRODUCTION}

In this study, the hierarchical classification of the Earth's postgenetic karsts is presented and then karst types are described. Karst is defined as postgenetic one when karstification takes place after the development of the rock, while it is syngenetic when they happen simultaneously. Although the collection and description of various types are based on literature, the classification of the Earth's karsts as a uniform system and the hierarchical character of the classification is a new perspective. The introduction of the various types of karst areas, the classification according to surface morphology and the classification of cryptokarsts according to several viewpoints can also be regarded new results.

Taking their characteristics into consideration, karst areas can be categorized into karst types. In this study, karst types are described, then the conditions of their development, the main characteristics of their karstification and their characteristic features are overviewed. Classification of karst is important since karst processes can be better overviewed and understood, and it may also contribute to the exploration and the development of a karst area. Grund (1914) and Cvijič $(1925,1918)$ also classified karst areas as karst types. Later works classifications involved more and more characteristics of karsts (White, 1988; Jakucs, 1977; Sweeting, 1973; Gvozdetskiy, 1965), and thus more and

*Corresponding author: veress.marton@sek.elte.hu

(C) The Author 2020. This article is published with open access at Springerlink.com

Manuscript received October 12, 2019.

Manuscript accepted January 3, 2020. more complex karst type systems were created.

Based on their characteristics (geology, climate, etc.), the karsts of the Earth can be classified in more than one way. Karst types can be divided into two large categories: static and dynamic (according to development) groups (Table 1). A static karst group gives the main characteristics of the categorized karst area at a given time. The karst type according to development expresses what development level a given karst area reached during its development (the development is caused by the autonomous development of the karst, but this may be influenced by external factors). The maturity of the karst can be studied in many ways. Thus, a point of view of classification can be the state (the degree of its denudation) of the surface of the karst, or classification may also be possible with the consideration of the development of the whole karst. The classification according to geomorphic evolution may be general which is more or less valid for all karsts and karst types and it may be special that is related to the geomorphic evolution of the karsts of some karst types. Karsts of static type may be azonal and zonal. The karsts of the azonal karst types may develop under any climate and they can be classified in several ways. Thus, their classification may be done based on the geology, elevation, expansion, hydrology and morphology of the karst. Zonal karst types are climate and biogenic dependent (Table 1). Every karst of the azonal karst type also belongs to the zonal karst type. Characteristics arising from zonality may manifest very differently on various azonal karsts.

The same karst area may also belong to several different azonal karst types (for example the karst areas of the Alps belong to the high-mountain karst type according to elevation, 
Table 1 Classification of karst types

\begin{tabular}{|c|c|c|c|c|}
\hline Group & Subgroup & Aspect of karst classification & Type & Subtype \\
\hline \multirow[t]{13}{*}{ Static karst } & \multirow[t]{12}{*}{ Azonal karst } & Age & Paleokarst, recent karst & Fossil karst, relict karst \\
\hline & & Rock & $\begin{array}{l}\text { Limestone karst, dolomite karst, marble karst, } \\
\text { gypsum karst, halite karst, sandstone karst }\end{array}$ & - \\
\hline & & Rock development & Holokarst, merokarst, transitional karst & - \\
\hline & & Structure & Platform karst, geosynclinal karst, horst-type karst & $\begin{array}{l}\text { Eugeosynclinal karst, } \\
\text { miogeosynclinal karst }\end{array}$ \\
\hline & & Cover & See Table 2 & - \\
\hline & & Morphology of its surface & Karren karst, doline karst, polygonal karst, mound karst & Pinnacle karst \\
\hline & & Elevation & $\begin{array}{l}\text { Coastal karst, plain karst, hill karst, low-, medium- } \\
\text { and high-mountain karst }\end{array}$ & - \\
\hline & & Expansion & $\begin{array}{l}\text { Block karst, karstschuppen, bed karst, plateau karst, } \\
\text { block plateau, karst block, stripe karst }\end{array}$ & - \\
\hline & & Karstwater temperature & Warm-water karst, cold-water karst & - \\
\hline & & Origin of water & $\begin{array}{l}\text { Autogenic karst, allogenic karst, mixed allogenic- } \\
\text { autogenic karst }\end{array}$ & - \\
\hline & & Water motion & Eogenetic karst, telogenetic karst & \\
\hline & & Effect & Glaciokarst, fluviokarst & - \\
\hline & Zonal karst & Climate & $\begin{array}{l}\text { Tundra karst, taiga karst, temperate karst, mediterranean } \\
\text { karst, subtropical karst, tropical karst: inselberg } \\
\text { karst, tropical karren }\end{array}$ & $\begin{array}{l}\text { Fengcong, fenglin, stone } \\
\text { forest karst, arête karst, } \\
\text { tsingy }\end{array}$ \\
\hline Dynamic & & Karst cycle (Grund, 1914) & Adolescent karst, mature karst, old karst & - \\
\hline \multirow[t]{2}{*}{ karst } & & Karst cycle (Cvijič, 1918) & Young karst, mature karst, senile karst & - \\
\hline & & $\begin{array}{l}\text { Tropical karst (Waltham and } \\
\text { Fookes, 2003) }\end{array}$ & $\begin{array}{l}\text { Juvenile karst, youthful karst, mature karst, } \\
\text { complex karst, extreme karst }\end{array}$ & - \\
\hline
\end{tabular}

while they belong to the glaciokarst karst type according to effects that influenced them). It may be also possible that some parts of a karst area can be classified as various karst types. In either case, the karstification of such karst areas is usually more complex and more diverse than the karstification of those which only belong to one karst type.

\section{CLASSIFICATION AND CHARACTERISTICS OF KARST TYPES}

\subsection{Static, Azonal Karsts}

\subsubsection{Karst types according to the geology}

Classification may be done according to the age of karstification, the constituting rock of the karst, the characteristics of the constituting rock (for example, structure, development) and considering the fact whether there is cover on the karstic rock and if it occurs what composition it has.

According to the age of karstification, the karst may be paleokarst and recent karst. Paleokarst became karstified in the geological history, its features are not active now, and they are mainly infilled and covered. Sweeting (1973) distinguished two varieties of paleokarst: a relict karst (the features did not become covered) and fossil karst (the features became covered, but later they may also have become exhumed). Recent karst is currently active, developing karst, but the start of the development of its features may have begun at different times. Jennings (1964) differentiated syngenetic karst when the development and karstification of the bearing rock is simultaneous.

According to the rocks constituting the karst, karst may be carbonate karst (limestone, dolomite, marble) evaporite karst (gypsum, halite, potash) and the karst of other rocks (for exam- ple sandstone) dissolving to a lesser and greater degree. Among carbonate and evaporate karsts, there is mainly a difference in the rate of dissolution which may also be manifested in the size and density of the developing features (for example if carbonate karst is compared with gypsum karst).

The difference may also result in the fact that the developing features become destroyed and the karst becomes covered with weathering residue (for example halite) to the effect of the great amount of precipitation. However, in the area of the temperate belt, the various dissolution intensity can also be seen in the difference of the features of the dolomite and limestone areas of carbonate karsts (Jakucs, 1977) (see below). The dissolution of these rocks takes place at low $\mathrm{pH}$.

Since the dissolution of the dolomite is also temperature dependent (water of $15{ }^{\circ} \mathrm{C}$ dissolves $\mathrm{CaCO}_{3}$, and water of $40{ }^{\circ} \mathrm{C}$ dissolves $\mathrm{MgCO}_{3}$ to a greater degree), in karsts with water of low temperature (temperate climate), the intensity of dissolution is lower (Jakucs, 1977). Therefore, in dolomite karsts with low water temperature, surface karst features occur more rarely, they are smaller (for example karren), and their shape may be different from the karst features of the limestone (for example the dolines are of small depth as compared to their diameter and thus, they have gentle slopes). However, under tropical climate where the waters are of higher temperature and thus, the dissolution of the dolomite is more intensive, the features of the dolomite do not differ from the features of the limestone (Jakucs, 1977).

Among evaporate karst, mainly gypsum karsts and halite karsts are widespread on the Earth. The dissolution of these rocks is independent of $\mathrm{pH}$. Halite karsts are mainly covered because of the fast dissolution of the halite. Uncovered halite 
karsts occur under dry climate or at places where the fast rise of halite (for example salt diapir) is in harmony with dissolution (Veress et al., 2011).

On gypsum, karren may occur on bare surfaces (but subsoil features can also be found), such as rillenkarren, trittkarren, rinnenkarren, wandkarren, pits, and grikes (Waele et al., 2017; Madonia and Sauro, 2009; Calaforra, 1996; Macaluso and Sauro, 1996). On halite, mainly karren features of flow origin (rillenkarren, rinnenkarren) are characteristic (Móga et al., 2018a; Veress et al., 2011). Among solution dolines, drawdown dolines are less specific, while point recharge dolines are more characteristic for example in gypsum karsts of Italy (Waele et al., 2017). Solution dolines may also form uvalas on halite. Upward stoping breccia pipes develop in evaporate karsts as a result of dissolution taking place at large depth too (Ford and Williams, 2007; Waltham et al., 2005; Lu and Cooper, 1997; Quinlan et al., 1986). Collapse dolines, caprock dolines and dropout dolines may also develop above them, on the surface of the cover, depending on the presence and quality of the cover. However, these features may have developed above already existing horizontal caves (Klimchouk, 2004; Klimchouk and Andrejchuk, 2003) and mines (Móga et al., 2017; Andrejchuk, 2002) and at sites of surface water supplies (Johnson et al., 2003). On evaporates, ponors with blind valleys are also specific at rock boundary (Móga et al., 2018b; Waele et al., 2017), but features functioning as ponors are also common. Thus, karstic depressions, for example caprock dolines function as ponors (Móga et al., 2018b; Baumgardner et al., 1982). On bare gypsum surface at water drainage sites developing at fractures (Kósa, 1981), such depressions develop into which surface waters are drained below the surface as a result of the fast dissolution of the rock. Poljes also occur on gypsum (Waele et al., 2017), while on halite depressions of large expansion (solution subsidence trough, solution-induced depositional basin) develop where a lot of breccia pipes are situated adjacent to each other (Klimchouk, 2004; Martinez et al., 1998). In evaporate karsts, depressions with lakes are specific (Milanovič et al., 2019). Both on gypsum and on halite, inflow caves, effluent caves and through caves are characteristic (Móga et al., 2018a; Waele et al., 2017). On halite, mainly in areas with dry climate there are expanded caves. On gypsum, vertical cavities (of shaft nature) are widespread (Szablyár, 1981).

On sandstone (sandstone karst) dissolution takes place in alkaline medium. The intensity and degree of dissolution depends on the minerals of the sandstone, the temperature and the duration of dissolution. The dissolution of sandstones is mainly enabled by better soluble minerals with a cementing effect (Veress and Tóth, 2015; Briceño and Schubert, 1990). Mainly amorphous silica gets into solution if the temperature and the $\mathrm{pH}$ of the water is high and the duration of dissolution is several hours or days (White, 1988; Siever, 1962; Siffert, 1962). However, the process is retarded by the weak water drainage capacity of the rock: if the dissolved material is not able to be transported, it is precipitated. Therefore, on sandstone small-sized features (karren) are widespread such as kamenitzas (though, these may have a diameter of several meters), grikes, rinnenkarren, chimneys, notches (Veress and Tóth, 2015), but on quartz sandstone, pinnacles, towerkarsts, labyrinths, giant grikes, dolines, corridors and shafts which developed by dissolution may also occur (Wray, 1997). On sandstone, caves of significant size may also develop by dissolution which often form a complicated network or a system of streams (Wray, 1997; White, 1988).

The classification according to the development of the bearing rock originates from Cvijič (1925). He distinguished holokarst (the karst is built up of karstic rock in large thickness), merokarst (karstic rocks are interrupted by non-karstic rock intercalations) and transitional karst (the karstic rock is bordered by non-karstic rocks on the sides). In holokarst karstification may take place without hindrance. Here, there is a great chance of the development of complex, expanded karst systems. In merokarst and in transitional karst, karstification is limited spatially (nonkarstic processes also exert their effect in alternation or mixing with karstic processes).

According to the structure of the bearing rock, platform-type karst, geosyncline karst (Komatina, 1982) and horst-type karst (Leél-Őssy, 1959) are distinguished. In the area of platform-type karst, as a result of compression, the beds are horizontal which may be interrupted by terrestrial, non-karstic beds. In the karsts of this karst type morphological dissectedness and the velocity of water flow is small, cavities are horizontally developed (Komatina, 1982).

In geosyncline karst, which is separated from eugeosyncline karst and miogeosyncline karst, the deformation of the beds due to tectonic powers was significant, as a result of which folded structures and nappe structures developed which may have undergone significant protrusion. To the effect of the latter, in the karsts of this type, vadose zone is where thick and vertical water flow systems develop, the climate is vertically zonal in their area. The karsts of this type belong to high-mountain karst and to glaciokarst. Horst-type karst is separated into blocks. Adjacent blocks often have different characteristics (elevation, the degree of coveredness), thus the degrees of their karstification depending on their coveredness, their karst types, and the time of their karstification may also be different (Veress and Vetési-Foith, 2019; Veress, 2016, 2000).

According to the non-karstic cover of the karst, Gvozdetskiy (1965) distinguished bare karst (there is karstic rock on the surface), soil-covered karst (the karst is covered by soil or dissolution residue, Fig. 1), covered karst (the karst is covered by non-karstic rock) and buried karst (where no karstification occurs because of the large thickness of the cover). Hevesi (1986) stated

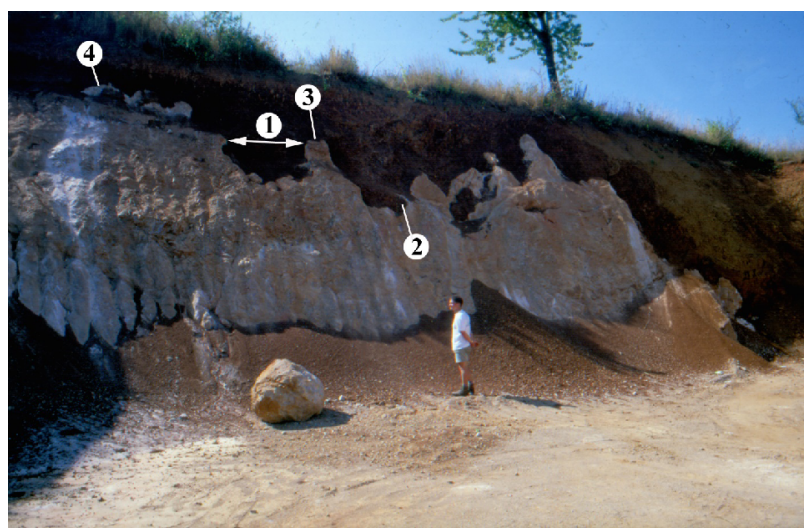

Figure 1. Subsoil grike (Croatia, mine wall next to main road Number 1); the cover is solution residue: 1 . grike; 2. kamenitza-like depression on the floor; 3 . ridge between grikes; 4 . detached section of bedrock. 
if there is non-karstic cover on the karst, it may be covered, non-individual (there is no karstic rock at the surface) and partly covered. He distinguished buried karst or closed karst (the cover is impermeable) and concealed karst (the cover is permeable) within covered, non-individual karst. Since one of the subsidence doline varieties (dropout doline) also develops on clay cover, covered karsts where the cover is unconsolidated, but cohesive and impermeable rock, superficial deposit can also be regarded as concealed karsts (Veress, 2016). Covered karst is present in several karst areas of the Earth to a larger and smaller expansion. It mainly occurs at sites where there have been not enough time for the denudation of the superficial deposit (in glaciokarst, the moraine, under temperate climate, the loess) or the superficial deposit redevelops (under tropical and Mediterranean climates the weathering residue), or the superficial deposit is not able to be destroyed or it is, but only to a small extent (karst depressions, the valleys of the karst). The features of these karst types are different too. Thus, on soil-covered karst, subsoil karren (grikes, kamenitzas, etc.), while on uncovered surface, karren of bare surfaces (in addition to the above mentioned features, rinnenkarren, rillenkarren, etc.), solution dolines, collapse dolines and uvalas are formed, in buried karst, caprock dolines are specific, in concealed karst, the varieties of subsidence dolines, dropout dolines and suffosion dolines develop (Veress, 2016; Ford and Williams, 2007; Williams, 2004).

Taking the cover into consideration, Quinlan (1978) distinguished subsoil karst, mantled karst, buried karst, interstratal karst and subaqueous karst. In subsoil karst, the cover is either the sediment that was carried over the karst or the weathering residue that was produced in situ. In mantled karst, the cover is consolidated rock or allochthonous sediment. The karst is older than its cover. The mantled karst is a part of the karst landscape. In buried karst, the cover is allochthonous rock or sediment. The karst is older than its cover and it is not part of the karst landscape. Interstratal karst is covered by autochthonous rock or sediment and this karst is a part of the karst landscape. The karst is younger than its cover. The subaqueous karst is a subsided karst. Thus, it is located either under the sea level or under a river (Table 2).

Veress (2016) distinguished four varieties of cryptokarst: allogenic cryptokarst, autogenic cryptokarst, transitional cryptokarst and cryptokarst developed from buried karst (Table 2). Allogenic cryptokarst corresponds to the mixed allogenic-autogenic cryptokarst described in literatures (see below), if the non-karstic rock is superficial deposit and not wedged-in rock. On the autogenic cryptokarst, karstification takes place within the impervious rock, where there is local water transfer into the karst from the cover. However, this variety also includes areas with thick impermeable cover, where the bedrock is evaporite. Evaporites located in great depths may become dissolved in this case too and thus, they affect the cover (collapse, subsidence). On transitional cyrptokarst, karstification may take place within the cover, but at its termination too. Within the cover, the karstification is similar to that on autogenic cryptokarst, while at its margin it is similar to that which takes place at rock boundary. On cryptokarst developed from buried karst, there is karstification where the epigenetic valleys opening up the impervious rock reach the bedrock. This variety corresponds to allogenic karst type described in literatures (see below).
According to Veress (2016), based on its development, covered (crypto) karst may be renewed allogenic covered karst, semi-allogenic covered karst, mantled allogenic covered karst, and horst covered karst (Table 2). By the present days, renewed covered karst has become separated (either it becomes elevated or it is separated by a valley) from its non-karstic sediment sources (Figs. 2a, 2b). The uncovered part of the semi-allogenic covered karst is crossed transversely by epigenetic valleys originating from the non-karstic terrain (Fig. 2c). In case of suitable conditions, the watercourses of the valleys transport the sediments of the non-karstic terrain out of the karst. On mantled karst, the karst is covered by consolidated impermeable rock. The pattern of the features of mantled karst on the karst depends on the characteristics of the consolidated impermeable rock (to what extent it contains fractures or its thickness, Fig. 2d). On horst covered karst, there are blocks being covered to a various extent adjacent to each other (the quality, thickness and expansion of the cover is different) and as it has already been mentioned, the karst type (Fig. 2e), the karstification of these blocks may be different too.

The latter classifications (Veress, 2016) enable a detailed analyses of cryptokarst according to its character and development since cryptokarst is not homogenous, but several varieties can be found in karsts on the Earth.

\subsubsection{Karst types according to the morphology}

In case of the dominance or absolute presence of a karst feature, karren karst, doline karst (Dicken, 1935), polygonal karst (Ford and Williams, 2007) and mound karst can be distinguished. Karren are predominant on surfaces with karren, while dolines of various size and type prevail on surfaces with dolines. On polygonal karst (Fig. 3), as a result of doline widening, only mounds and dividing walls survived from the original terrain between the coalesced dolines (Williams, 1985). The tropical variety of the latter is the cockpit karst (Waltham, 2008). On mound karst mounds with various size and shape such as karst hills, pinnacles and inselbergs are widespread. According to Ginés (2009), karsts where pinnacles, which are large-sized remnant megakarren are predominant, are pinnacle karst.

\subsubsection{Karst types according to the elevation}

According to the elevation of the karst, there are coastal-, plain-, hill-, low-, medium-, and high-mountain karsts. On karsts with a more and more elevated surface, the amount of precipitation increases, the average annual and daily temperatures, the number of frost-free days (and thus, the biological activity of the soil) as well as the degree of the coveredness of the surface (regarding both the non-karstic cover and vegetation) decrease, while the thickness of the vadose zone increases. As a consequence of the above mentioned differences, the intensity and duration of karstification as well as the flow system of the karst and thus, the character of cavity formation will be different on karsts with various elevations.

Among them, coastal karst has further special properties as a result of the effect of the bordering sea and lake. Coastal karst ranges from the low-tide level to the upper level of the supratidal belt, but the terrestrial effect is increasingly stronger over the high tide level. As a result of the subsidence of the land or the rise of 


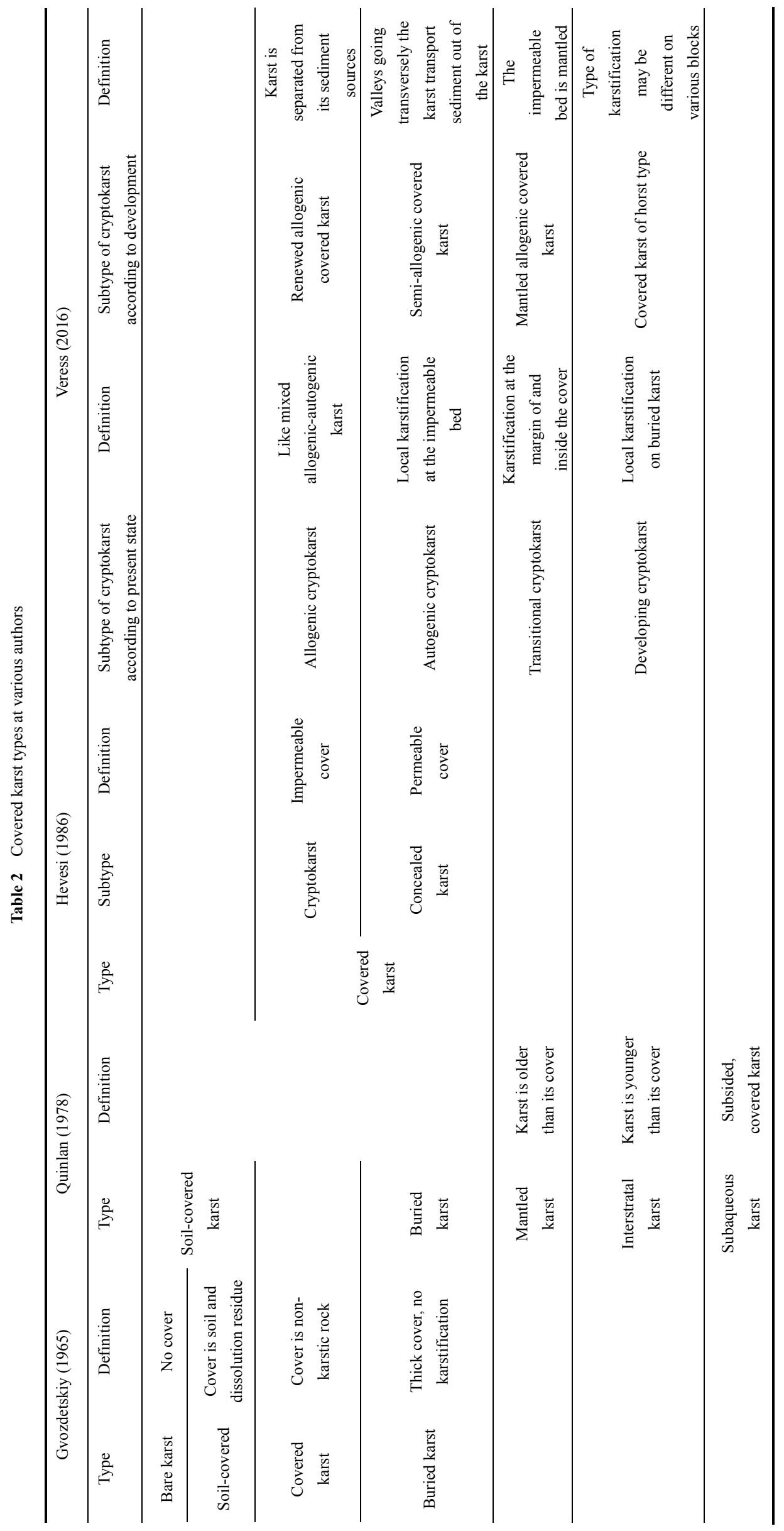


(a)
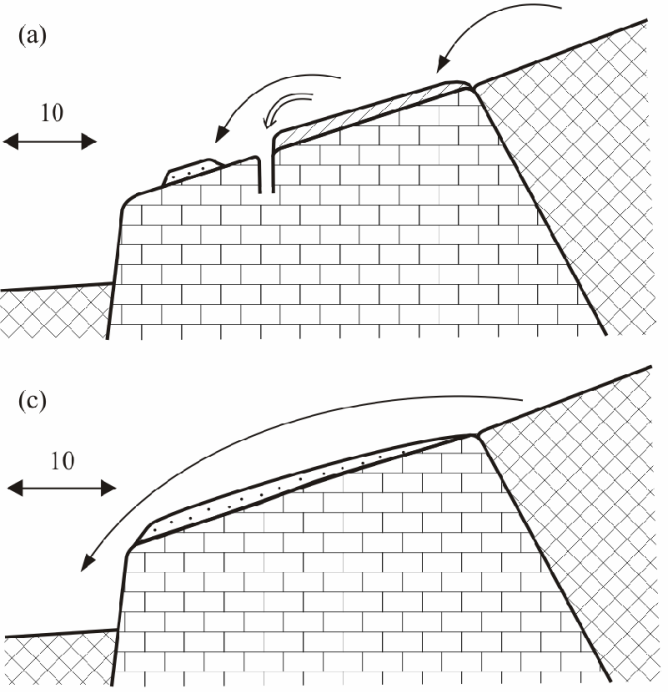

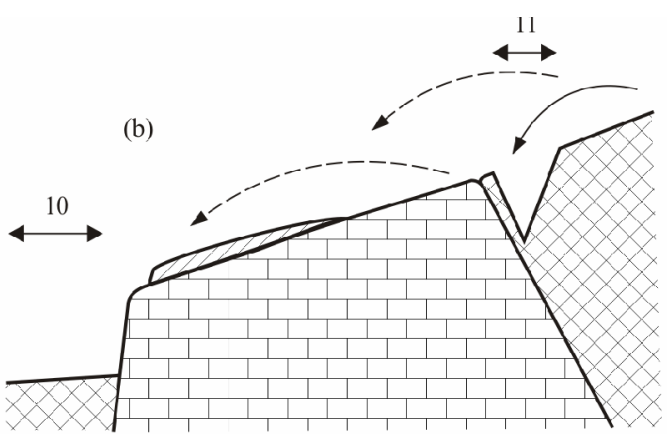

(d)
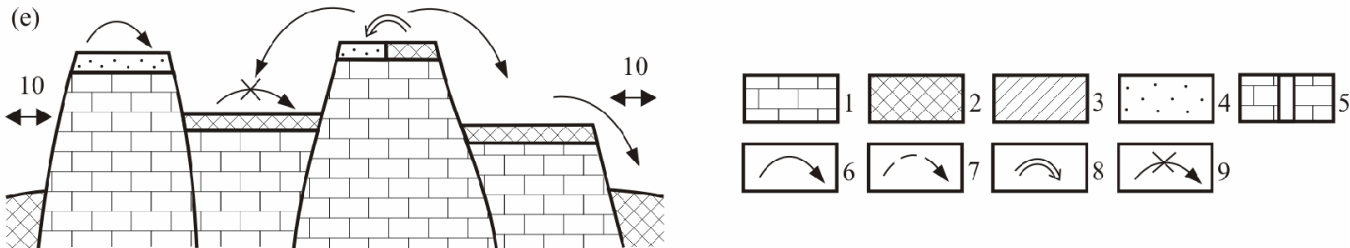

Figure 2. Theoretical profiles of medium-mountain covered karst types (Veress, 2016). (a) Recent allogenic covered karst; (b) renewed allogenic covered karst; (c) semi-allogenic covered karst; (d) mantled allogenic karst; (e) horst covered karst. 1. Limestone; 2. consolidated non-karstic rock; 3. unconsolidated, impermeable cover sediment; 4. permeable cover; 5 . chimney, shaft; 6 . sediment transport; 7. former sediment transport; 8 . transport of cover sediments into the karst hollows; 9 . no transport of superficial sediment from the block; 10 . mountain foreland; 11. valley.

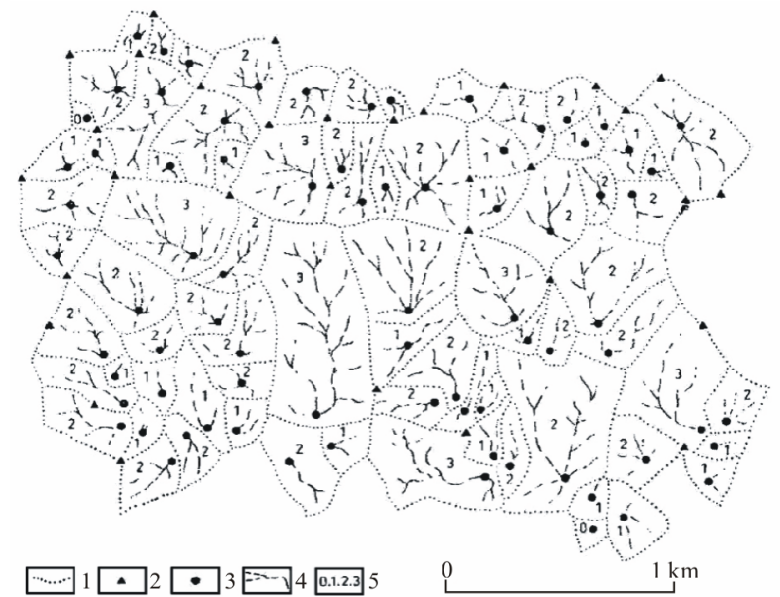

Figure 3. Polygonal karst (Williams, 1971). 1. Topographic divide; 2. summit; 3. swallet; 4. stream channel; 5 . basin order according to channels.

the sea level, the cavities and springs of the karst get below the water level, cave development ceases, and depressions with lakes develop on the shore. The cavities of the karst may open up or may be transformed by abrasion. Sediment formation and karstification may alternate in the zone of low tide level and high tide level. Karstification takes place on abrasion platforms and cliffs. Karren are formed partly by $\mathrm{CO}_{2}$ produced by organisms (Jennings, 1985), and by karst water added to sea water (Back et al., 1984) and by mixture corrosion (Lundberg, 2009) and by bio- erosion (McLean, 1974). Dissolution takes place simultaneously on bare surface (bare karren) and below the soil (subsoil karren) adjacent to each other (Gómez-Pujol and Fornós, 2009). Among karren, basins of various sizes, notches and grikes prevail, however there are differences in feature development in various climate belts (Veress, 2019).

\subsubsection{Karst types according to the expansion}

Karst with an expansion larger than $1 \mathrm{~km}^{2}$ and built up of karstic rock with a thickness larger than $40 \mathrm{~m}$ is called block karst, while karst with an expansion smaller than $1 \mathrm{~km}^{2}$ and built up of karstic rock with a thickness larger than $40 \mathrm{~m}$ is called karstschuppen, and karst built up of rock with a thickness smaller than $40 \mathrm{~m}$ is called bed karst (Rónaki, 1970; Venkovits, 1959). Based on Hungarian examples, Leél-Össy (1960, 1959) distinguished karst plateau, karst block plateau and karst block. The karst plateau has an expansion of 50-100 $\mathrm{km}^{2}$ (or it may be greater than this). The karst block plateau developed by the dissection of the plateau is a plateau part with an expansion smaller than the previous one. Karst blocks are tectonically separated mountains with steep slopes. If the karstifying rock outcrops on the surface in small width, but in large length, it is called stripe karst (Skoglund et al., 2010; Lauritzen, 1984; Horn, 1935). Karsts of such type occur in the Scandinavian Peninsula, where marble and non-karstic rocks alternate in the area of folded structures. Probably, the larger the expansion and the smaller inclination the surface of the 
karst, the greater the chance of the development of varied karst phenomena and of karst systems with diversified composition.

\subsubsection{Karst types according to the hydrology}

Taking karst hydrology into consideration, thus, classification may be based on the temperature, the permeability of the karst, and the place of origin of karstwater. According to the temperature of karstwater, cold-water karsts and thermal karsts (warm-water) can be distinguished. Karst is cold-water karst when the temperature of its karstwater is lower than the regional annual average temperature, but it is thermal karst if it is higher. Thermal karst develops at sites where the karst water is heated up by the Earth's internal heat. Heating up may also be caused by the heat originating from the magma developing near the karst or by heating up or rising other waters getting to a lower depth (Erőss, 2010; Kovács and Müller, 1980; Alföldi and Lorberer, 1976). On thermal karst, large-sized, labyrinth patterned caves developed by warm waters are common and in the cavities of the karst, minerals (for example aragonite) that were formed in a warm-water environment occur (Leél-Össy, 2017). The upper, more elevated part of the karst is often cold-water karst, while its lower part is of warm water features.

Regarding the matrix peremability of the karstic rock eogenetic and telogenetic karst can be distinguished (Florea and Vacher, 2006). The study of these karsts is of high practical importance because of the change of peremability. Eogenetic karst was investigated for example in China (Liu et al., 2019).

According to the place of origin of karstwater, Jakucs (1977) distinguished autogenic and allogenic karst. The surface of autogenic karst is more elevated than the surrounding, non-karstic terrain and the surface of this latter terrain does not dip towards the karst. Therefore, only meteoric water gets into its area (Fig. 4a). On autogenic karst, solution features (solution dolines, uvalas, karren) are widespread.

On allogenic karst, the non-karstic surface surrounding the karst dips towards the karst. This karst also receives water from the surrounding terrain. At the interface of the karstic and non-karstic rocks (rock boundary), ponors with blind valleys develop as a continuation of the latter with erosion caves. In the part of allogenic karst which goes beyond the rock boundary there may also be features of autogenic karst (dolines, karren), but epigenetic valleys are also characteristic.

This classification was improved and the notion of mixed allogenic-autogenic karst was introduced (Ford and Williams, 2007). According to Ford and Williams (2007), on allogenic karst, non-karstic impermeable cover is predominant. The karstic rock is exposed at epigenetic valleys (Fig. 4b). On valley floors, solution (drawdown) dolines develop and/or at valley rock boundary, ponors (Hevesi, 1986; Jakucs, 1977) and point recharge dolines may be formed (Sauro, 2012). The latter are dolines which receive the water of the stream of the valley floor. Autogenic karst features are present on the uncovered karst surface, beyond the rock boundary, on mixed allogenic-autogenic karst type (Fig. 4c, this karst type corresponds with the allogenic karst type of Jakucs's classification). Drainage is diffuse on autogenic karst, it is point-like on allogenic karst and both diffuse and point-like on mixed allogenic-autogenic karst.

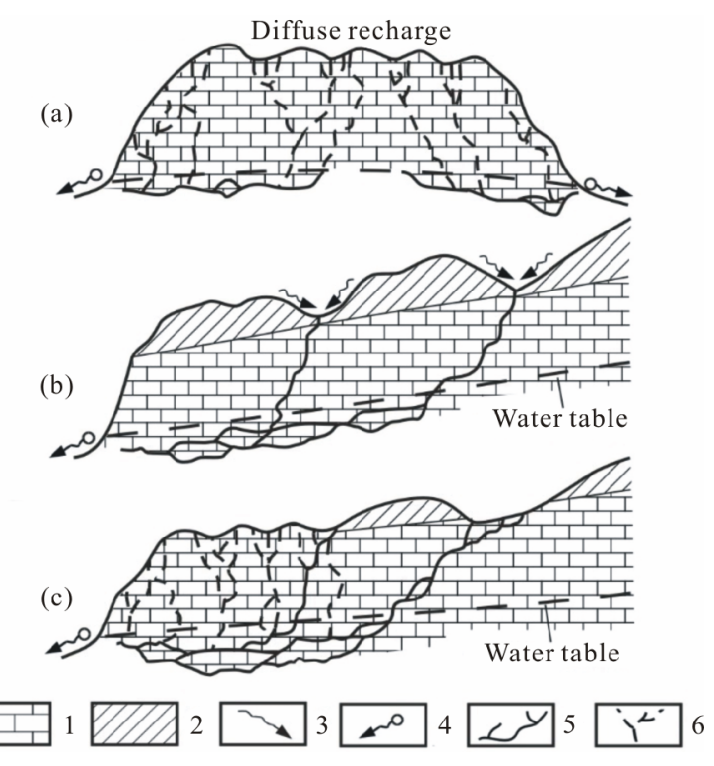

Figure 4. Autogenic (a), allogenic (b), and mixed allogenic-autogenic karst (c) (Ford and Williams, 2007). 1. Limestone; 2. impermeable cover; 3. watercourse; 4. spring; 5 . stream subsystem; 6 . percolation subsystem.

\subsubsection{Karst types according to affected impacts}

According to significant, non-karstic surface formation processes affecting karsts, glaciokarst and fluviokarst can be distinguished.

Glaciokarst (Fig. 5) is karst formerly exposed to glacial erosion (Sweeting, 1973). Glaciokarst also occurs on more elevated terrains in the karst areas of lower latitudes, and on less elevated terrains (British Islands) in karst areas of higher latitudes. According to Ford (1979), its features can be of karstic glacial origin (glacial features were transformed by karst processes), of glacial karstic origin (karst features were transformed by glacial erosion) and of mixed origin (features were affected several karst and glacial processes at different times). The development age of karst features is diverse. They may be of preglacial (Pleistocene), interglacial or postglacial age (Ford, 1979).

On glaciokarst, according to coveredness, varied karst types occur, even adjacently to each other (partly as a result of diverse elevation, partly because of the stream load of ice). Thus, bare karst, soil-covered karst, concealed karst and mixed allogenicautogenic karst can also occur (Veress et al., 2019). Its covered karst is specific since the cover (moraine) is mostly completely or partially limestone debris. Thus, the infiltrating water often becomes saturated already in the cover and in this case it does not exert a dissolution effect on the bedrock any more.

The intensity of dissolution is extremely various partly because of the presence or lack of soil or because of the differences in the biological activity of the soil. As elevation increases, the duration of dissolution related to the soil is increasingly shorter because of shorter summer, but the duration of dissolution may also be longer on bare surfaces as a result of the great amount of snow and its slow melting. In addition to dissolution, frost weathering and mass movements are significant landscape shaping processes.

Valley glaciers created troughs and cirque valleys, while ice caps and ice sheets created slightly dissected plain surfaces. The small features of surfaces of glacial erosion are roches 


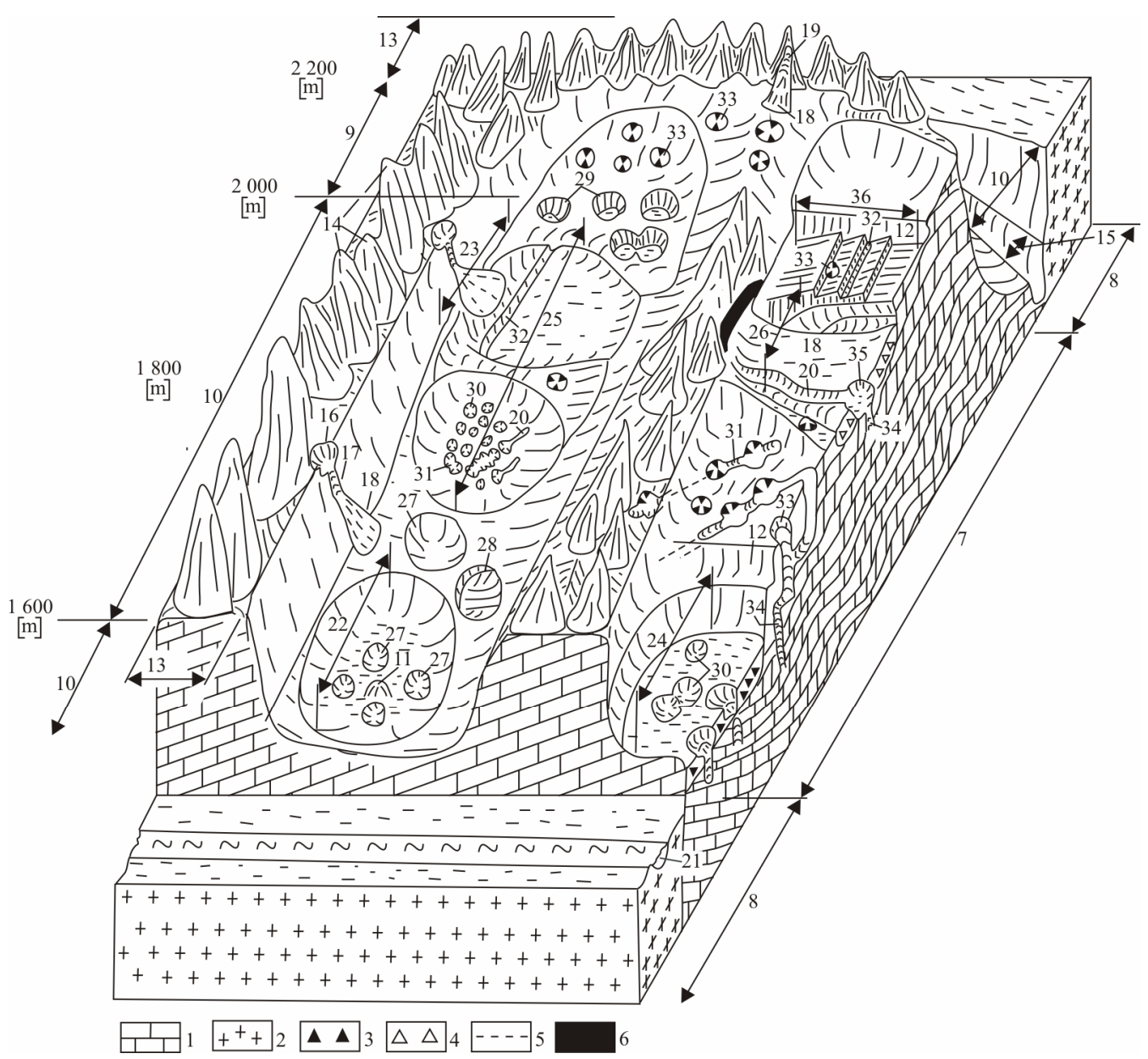

Figure 5. Main features in the glacially transformed karstic high mountains based on the example of the Alps (modified after Veress, 2010). 1. Limestone; 2. older metamorphic basement; 3. moraine; 4. colluvial debris; 5. fault; 6. siliceous interbedding in limestone; 7. klippen (plateau); 8. eroded portion of nappe; 9. cirque; 10. trough; 11. roche moutonnée; 12. tarn backwall; 13. arête; 14. horn; 15. river valley; 16. niche with circular rim; 17. niche of frost shattering; 18. talus cone; 19. path of rock avalanche; 20. furrow of covered karst depression; 21. river; 22. paleodoline; 23. asymmetric paleodoline; 24. paleodoline with moraine; 25. paleouvala; 26. partially filled paleodoline; 27. recent solution doline; 28. recent asymmetric solution doline; 29. schachtdoline; 30. subsidence doline; 31. subsidence uvala; 32. giant chasm (bogaz); 33. shaft system; 34. passage, chimney, shaft system in cross-section; 35. ponor; 36. schichtrippenkarst.

moutonnées, rock basins and stepped surfaces (Veress et al., 2019). The latter is called "Schichttrippenkarst", and "Schichttreppenkarst" by Bögli (1964), "limestone pavement" by Williams (1966) (Fig. 6). Features of karstic origin are various doline varieties, karren, shafts, poljes, ponors and gorges (Veress et al., 2019; Veress, 2017; Ford and Williams, 2007; Smart C, 2004; Smart P I, 1986; Kunaver, 1983; Sweeting 1973). Giant dolines are old, large-sized karst features developed by ice, on the floor of which, on the accumulated superficial deposit concealed karst often developed (Veress et al., 2019). On concealed karst surfaces (on the floor of giant dolines, on some parts of troughs and cirque valleys) subsidence (suffosion) dolines are widespread. However, on glaciokarst soil-covered terrains, small-sized solution dolines of postglacial age occur, while on bare surfaces there may be small-sized schachtdolines (with a diameter and depth of some meters) with steep slopes. Shafts are caves of large depth which mainly developed below glaciers (Ford, 1984). On glaciokarst terrains, both subsoil karren and bare karren are widespread. The latter is mostly dominant on the stepped surfaces of troughs. The most common karren features are rinnenkarren, rillenkarren, trittkarren, wandkarren and grikes (Veress, 2010).
Fluviokarst is karst subject to fluvial erosion (Sweeting, 1973). In karst areas belonging to this type, in addition to karstification, fluvial landscape formation is also present because of the partial presence of non-karstic cover. Therefore, in addition to karst features, valleys, epigenetic valleys and gorges also develop on the karst. The landforms are often mixed. Thus, on the floor of epigenetic valleys, ponors with blind valleys and doline rows may occur.

\subsection{Static, Zonal Karsts: Karst Types According to Climate}

The dependence of karst on climate can be direct and indirect. Direct in a way that the quantity, distribution and quality of precipitation affects dissolution. However, temperature is also an important factor mainly because there is no dissolution and material transport below a temperature of $0{ }^{\circ} \mathrm{C}$. If ground ice is present, and if there is any water of liquid state, it does not reach the rock and thus, dissolution is not possible. The indirect role of climate is effective through the soil and its biological activity. The greater the quantity of precipitation, the higher the temperature and the more long-lasting their effect is, the greater the biological activity of the soil through the organisms living in the soil. This results in 


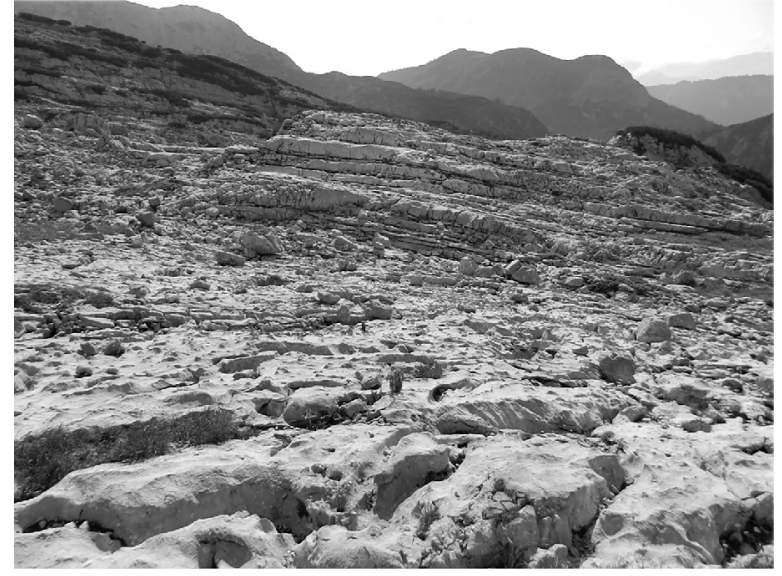

Figure 6. The stepped surface of a trough (the stepped are constituted by bedding planes and bed heads) with rinnenkarren in the foreground of the picture (Totes Gebirge).

greater $\mathrm{CO}_{2}$ production and thus, in more intensive dissolution (Trudgill, 1985; Jakucs, 1977).

On tundra karst, karstification is not favoured by the late cessation of ice cover, the presence of permafrost and the short-term liquid state of water, the lack or patchy development of the soil cover. Karstification is possible where heat is transmitted from below into the karst (Van Everdingen, 1981), where there are surface streams (Ford and Williams, 2007), or salty ground waters (Pollard et al., 1999). Karstification may also occur at steep cliff walls (Lauriol and Gray, 2006), on terrains with breccia (Ford, 2004) and where snow meltwater flows on bare surfaces. According to the above mentioned things, there are karren on bare surfaces, while caprock dolines occur can be found on evaporate areas.

Temperate karsts are also diverse due to the diversity of the climate, but the karstification of the karsts of various climate types often differs only to a small extent. On taiga karst (in the northern part of the boreal climate, areas with subpolar climate belong to here where the winter is $6-9$ months long) permafrost is widespread, but there is soil, and biological activity is also present during the summer. Karstification is not significant because of the low intensity of biological activity, the low quantity of precipitation and the presence of permafrost. On bare surface parts, slight karren formation may develop. On the floor of epigenetic valleys, there are small solution dolines (Veress et al., 2014; Pulina, 2005) and subsidence dolines, while on the interfluves mainly subsidence dolines occur (Veress, 2016). Complex systems may also develop: in larger depressions with several doline groups (Gvozdetskiy, 1981; Korzhuev, 1961). At the edge of non-karstic rocks, ponors may also develop.

From the boreal belt towards the Equator, at the middle latitudes, the climate with long summer (close to the ocean there is a climate with cool summer and farther from the ocean a climate with hot summer), then areas of subtropical climates can be found.

In the area of middle latitudes, the intensity and duration of dissolution increases. This can be attributed not only to the larger quantity of precipitation and to the long frost-free period, but also to the significant biological activity of the soil. On its karst, subsoil karren (mainly grikes and root karren), dolines and uvalas are widespread. In addition to erosion caves, solution caves are also widespread. The high dissolved material content of waters favours the development of freshwater limestones (calcareous sinter) (Jakucs, 1977).

Dissolution takes place during whole year in karst areas of subtropical, but mainly of Mediterranean climate. The intensity of dissolution is enhanced by the great biological activity of the soil. In the areas where mainly subsoil karren is characteristic, but on bare slope sections (for example in the side of mounds), bare karren is also common. In these karst areas the doline landscape is much more specific. The density of dolines is large, doline systems and uvalas may develop. A specific feature of Mediterranean karst is the polje, of which several genetic and morphological varieties are distinguished (Gams, 1978). Among them there are poljes which are formed by glacial effect such as piedmont poljes (Gams, 1978; Sweeting, 1973), and those which are temporarily or permanently affected by karstwater. Subsidence dolines are common on polje floor sections with superficial deposit (Veress, 2016). Covered (concealed) karst also occurs on the floor of other karst depressions (dolines, uvalas). Remnants features are widespread because of intensive dissolution. The intensive widening of dolines results in the development of polygonal karst and terrains with karst hills. Large-sized caves of various genetics are characteristic. The high dissolved material content of waters favours the development of large-sized freshwater limestone features at karst springs and in the channels of streams.

Tropical karst areas of the tropical climate developed under tropical wet, tropical savanna and tropical monsoon climates. Karstic dissolution is the most intensive here on Earth, because of large quantity of precipitation, high temperature all year round, but mostly because of great biological activity of the soil, this latter originates from the above mentioned factors. In addition to these, significant karstic denudation was also contributed by the fact that karstification has been taking place for several 10 million years in areas of tropical climate and it was not interrupted by glacial periods and young transgressions.

On tropical karst, mounds (karst mountains) prevail. This is inselberg karst. Basically, two varieties of tropical karst are distinguished, the fengcong and the fenglin (Fig. 7, Waltham, 2008). Fengcong is constituted by mountains with a common base, where there are dolines (fengcong doline) between the mountains. A variety of fengcong is cockpit karst, where there are large-sized depressions (cockpit doline) between the mountains and the ridges connecting them (Williams, 1985; Sweeting, 1973). On fenglin karst, the mountains are solitary, and they are situated at various distances from each other. There are intermountain plains between the mountains. Karst water level is situated below the floors of fengcong depressions, while it is at the level of intermountain plains in case of fenglin. In depressions and on intermountain plains, there are expanded concealed karst terrains with many subsidence dolines. Karren such as subsoil karren is widespread, but karren of bare surfaces is also common, for instance rinnenkarren and kamenitzas on the top and on the steep slopes of inselbergs (Veress, 2019). Its large-sized karren constitutes a separate karst type (see below).

On tropical karst, the density of caves is large, their size and genetics is diverse. Thus, they may be of vadose, phreatic and 
erosional origin too. They occur in large numbers in karst inselbergs, where they may occur as the remnants of former foot caves (these drain the water of intermountain plains into the karst at the feet of inselbergs) in several levels (Waltham, 2008).

Among karst types according to climate, the most common and most widespread features are the concretions here
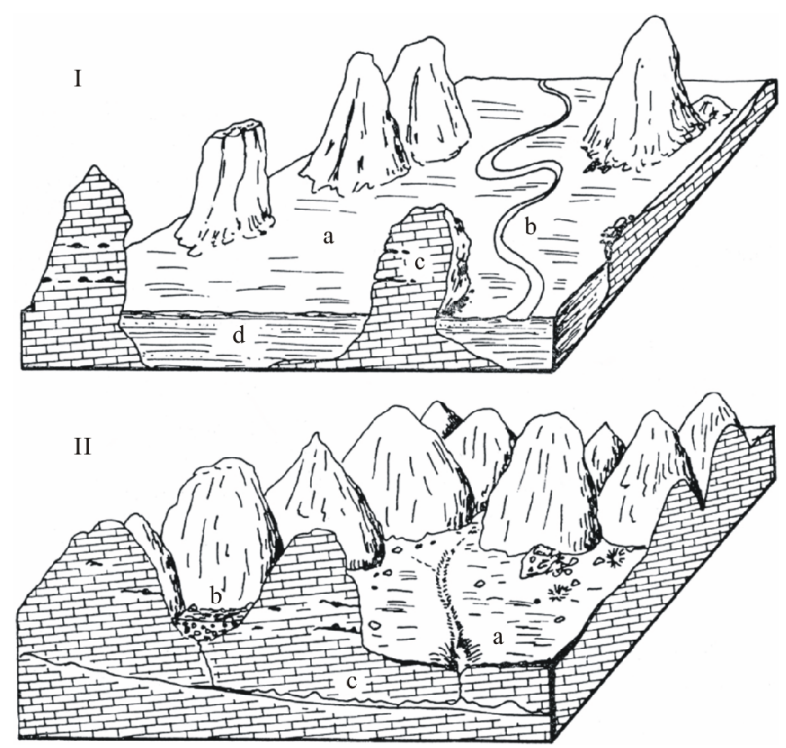

Figure 7. Inselberg karst (Balázs, 1986). I. Fenglin, a. intermountain plain, b. river, c. karst inselberg, d. alluvium; II. fengcong, a. ponor, b. doline, c. underground stream (active cave)

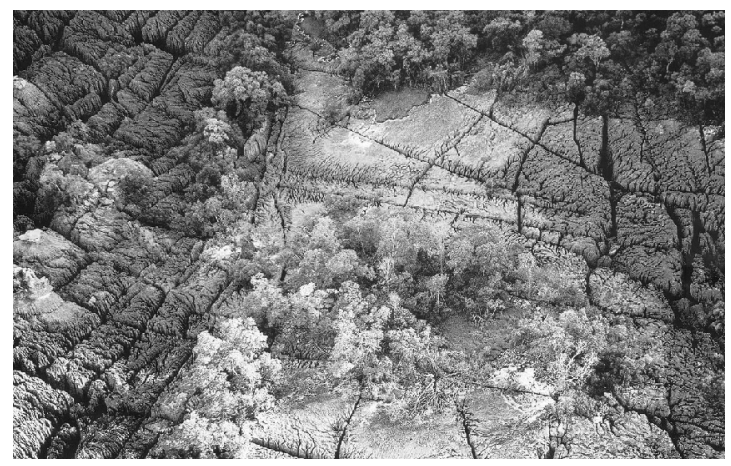

Figure 8. Tsingy (Bemaraha, Madagascar, Delaty et al., 2006). which occur at springs, in river channels, in the side of inselbergs and in caves too. Its large-sized karren types are the stone forest karst, the tsingy and the arête karst (pinnacle karst). Stone forest karst is characterized by towers with steep sides (Knez and Slabe, 2009), arête karst is characterized by ridges and mounds of less steep slopes (Day and Waltham, 2009; Williams, 2009), and while tsingy (Fig. 8) is characterized by grikes of various sizes (Veress et al., 2008). Bare karren of small or medium sizes (rillenkarren, rinnenkarren, kamenitzas, grikes, etc.) often occurs on the steep slopes and the top of the mounds of these karsts.

\subsection{Dynamic Karsts: Karst Types According to Development}

Karst development types can be distinguished, taking into consideration the denudation of the karst surface, as well as with the simultaneous consideration of the surface and subsurface denudation. Surface development and thus, classification may be different if the cover of the karst or the climate is also taken into consideration. The stages of surface development are followed by the development of different but characteristic landforms. Therefore, researchers used various karst type names for the surface development phases. Early researchers (following the Davisian cycle theory) called the denudation of the karst as karstic cycle, the end point of which is either the formation of a karstic peneplain (Grund, 1914) or the complete denudation of the karstifying rock (Cvijič, 1918) or maybe reaching the base level of erosion (Jakucs, 1977). Jakucs (1977) called this karst peneplained karst. This karst type mostly occurs on tropical karst. Here, intermountain plains were destroyed until the elevation of the surrounding non-karstic terrain (or until the karst water level). Taking into consideration the surface development of tropical non-karstic areas as described by Büdel, Cui et al. (2002) distinguished two levels: the surface of the bedrock and the surface of the weathering residue. The loss of the superficial deposit as a result of erosional, but not dissolutional denudation is supplemented by the weathering residue which was produced during the dissolution of the bedrock. On tropical karst, this state of equilibrium may permanently survive. Thus, the landforms of the karst surface survive and redevelop while the surface of the bedrock will be of lower and lower elevation (Veress, 2016). The karst regenerates and gets into an earlier surface development stage only if the base level of erosion gets into a lower position or the karst becomes more

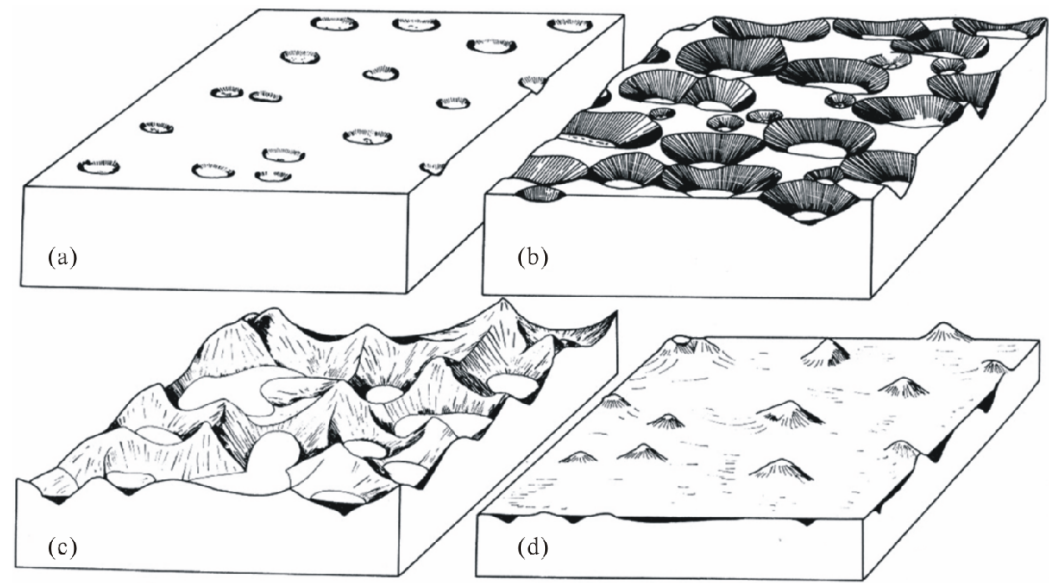

Figure 9. Geomorphic evolution of karst according to Grund (1914). (a) Young karst; (b) adolescent karst; (c) mature karst; (d) old karst. 


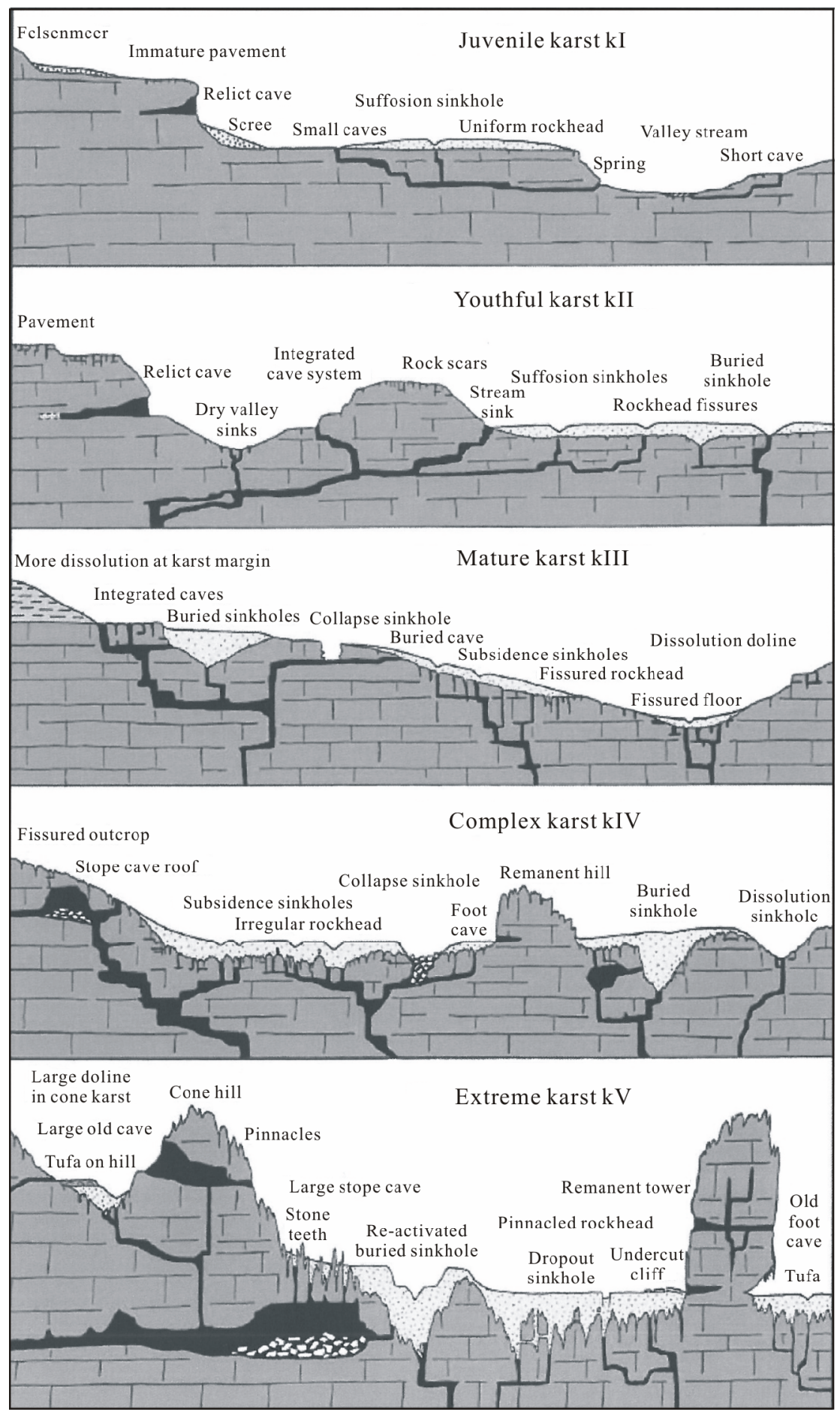

Figure 10. Karst types according to their landscape evolution (after Waltham and Fookes, 2003).

elevated. In case of a surface development this type of karst cycle, the longer duration karstification takes place under unchanged circumstances and the more intensive the karstification, the greater the chance for the karst to reach the end of the karst cycle.

Focusing only on surface karstification, Grund (1914) distinguished the following karst types on karst rock with any thickness during a karstification cycle (Fig. 9): young karst (its dolines are small), adolescent karst (with large-sized dolines, uvalas and the plain remnants of the original terrain), mature karst (the original terrain only survived on the top of mounds), and old karst (the roof level of mounds is also lower than the original terrain).
According to Cvijič (1918), there are karren, dolines, poljes, ponors and river valleys on young karst, while collapse dolines and cave-ins can be found on mature karst. Senile karst is characterized by river valleys which deepen into the non-karstic rock constituting the bedrock of the karst. Larger and smaller remnants of the karstic rock only occur on interfluves.

Focusing mainly on tropical karst, Waltham and Fookes (2003) distinguished five karst types (Fig. 10). On juvenile karst and on youthful karst, traces of non-karstic development are still recognizable (epigenetic valleys), but the former cover is not present any more. Karst features are less dominant and less di- 
verse, covered karst sections are of small expansion. On mature, the diversity of karst features is greater, the degree of cavity formation (and the inheritance of the cavities onto the surface) increases. On complex karst and on extreme karst, the amount of superficial deposit (weathering residue) is larger and larger, increasingly more and increasingly larger karst features develop (their infilling increases too) and the number of remnants features is also rising. Inselberg karst develops on extreme karst.

\section{CONCLUSIONS}

According to its constituting material, karst can be carbonate karst, evaporate karst and sandstone karst. Taking into consideration the characteristics of the constituting rock, holo karst, mero karst and transitional karst can be differentiated, while according to the structure of the constituting rock there is platform karst, geosyncline karst and horst-type karst. According to the cover, karst can be bare karst, soil-covered karst, buried karst and covered karst (the latter crypto karst and concealed karst). Cryptokarst may be karst developing from allogenic karst, autogenic karst, transitional karst and buried karst. According to its development, cryptokarst can be renewed allogenic covered karst, semi-allogenic covered karst and mantled allogenic covered karst. According to the morphology of its surface, karren karst, doline karst, polygonal karst and mound karst can be distinguished. According to its elevation, karst may be coastal-, plain-, hill-, low-, medium- and high-mountain karsts. According to its expansion, karst can be block karst, karstschuppen and stripe karst. According to the temperature of karst water there are cold-water karsts and warm-water karsts. With the consideration of water supplement conditions, autogenic karst, allogenic karst and mixed allogenic-autogenic karst can be distinguished, according to permeability, eogenetic and telogenetic karsts can be differentiated. According to non-karstic surface formation processes, glaciokarst and fluviokarst may be differentiated. Karst of zonal karst type can be tundra karst, temperate karst, subtropical karst and tropical karst. On the latter, fengcong karst, fenglin karst, cockpit karst and pinnacle (stone forest karst, tsingy, arête karst) karst are distinguished. In general, according to the development of the karst, young karst, adolescent karst, mature karst and old karst are distinguished. According to their landscape evolution, tropical karsts may be juvenile karst, youthful karst, mature karst, complex karst, extreme karst and peneplained karsts.

The presented classification may be suitable for the classification of a karst area as belonging to one or even several karst types based on the characteristics of the types. The classification facilitates either the theoretical or practical (e.g., environmental protection, ecology) study of karst areas, and future events, and changes may be predictable. Taking the characteristics of types into consideration, the anomalies of the former and present development of the karst area can be predicted (the difference from the usual development of the type).

\section{ACKNOWLEDGMENTS}

Thanks go to the reviewers and the editors for their useful suggestions and comments. Open access funding provided by Eötvös Loránd University (ELTE), Hungary. The final publication is available at Springer via https://doi.org/ 10.1007/s12583-020-1306-x.
Open Access This article is distributed under the terms of the Creative Commons Attribution 4.0 International License (http://creativecommons.org/licenses/by/4.0/), which permits unrestricted use, distribution, and reproduction in any medium, provided you give appropriate credit to the original author and the source, provide a link to the Creative Commons license, and indicate if changes were made.

\section{REFERENCES CITED}

Alföldi, L., Lorberer, Á., 1976. A Karsztos Kőzetek Háromdimenziós Áramlásának Vizsgálata Kútadatok Alapján (A Study of the ThreeDimensional Flow of Karst Rocks Based on Well Data). Hidrológiai Közlöny, 10: 433-443 (in Hungarian)

Andrejchuk, V., 2002. Collapse above the World's Largest Potash Mine (Ural, Russia). International Journal of Speleology, 31(1/4): 137-158. https://doi.org/10.5038/1827-806x.31.1.8

Back, W., Hanshaw, B. B., Driel, J. N., 1984. Role of Groundwater in Shaping the Eastern Coastline of the Yucatan Peninsula, Mexico. In: La Fleur, R. G., ed., In Ground Water as a Geomorphic Agent. Allen-Unwin, Boston. 281-293

Balázs, D., 1986. Kína Karsztvidékei (Karst Regions in China). Karszt és Barlang, II: 123-132 (in Hungarian)

Baumgardner, R. W., Hoadley, A. D., Goldstein, A. G., 1982. Formation of the Wink Sink, a Salt Dissolution and Collapse Feature, Winkler Country, Texas. University of Texas at Austin, Bureau of Economic Geology, Report of Investigations, 114: 38

Bögli, A., 1964. Le Schichttreppenkarst. Un Exemple de Complexe Glaciokarstique. Revue Belge de Geographie Ed. Soc. Roy. Geogr. Special Publ. Karst el Climats Froials, 88(1/2): 64-82

Briceño, H. O., Schubert, C., 1990. Geomorphology of the Gran Sabana, Guayana Shield, Southeastern Venezuela. Geomorphology, 3(2): 125-141. https://doi.org/10.1016/0169-555x(90)90041-n

Calaforra, J. M., 1996. Some Examples of Gypsum Karren. In: Fornos, J. J., Ginés, A., eds., Karren Landforms. Universitat de les Illes Balears, Palma de Mallorca. 253-260

Cui, Z. J., Li, D., Feng, J., et al., 2002. The Covered Karst, Weathering Crust and Karst (Double-Level) Planation Surface. Science in China Series D, 45(4): 366-378. https://doi.org/10.1360/02yd9038

Cvijič, J., 1918. Hydrographie Souterraine et Évolution Morphologique Du Karst. Recueil des Travaux de l'Institut de Géographie Alpine, 6(4): 375-426. https://doi.org/10.3406/rga.1918.4727

Cvijič, J., 1925. Types Morphologiques des Terrains Calcaires. C. R. Acad. Sci., Paris

Day, M., Waltham, T., 2009. The Pinnacle Karrenfields of Mulu. In: Ginés, Á., Knez, M., Slabe, T., et al., eds., Karst Rock Features. Karren Sculpturing Zalozba ZRC. Institut za Raziskovanje Krasa ZRC SAZU, Postojna. Carsologica, 9. 423-432

Delaty, J. N., Dobrilla, J. C., Wolozan, D., 2006. Observation Concernant les Tsingy de Madagascar et Plus Particulièrement Ceux de Bemaraha. Spelunca, 103: 39-44

Dicken, S. N., 1935. Kentucky Karst Landscapes. The Journal of Geology, 43(7): 708-728. https://doi.org/10.1086/624363

Eröss, A., 2010. Characterization of Fluids and Evaluation of Their Effects on Karst Development at the Rózsadomb and Gellért Hill, Buda Thermal Karst Hungary: [Dissertation]. Eötvös Lóránd University, Budapest. 171

Florea, L. J., Vacher, H. L., 2006. Springflow Hydrographs: Eogenetic vs. Telogenetic Karst. Ground Water, 44(3): 352-361. https://doi.org/10.1111/j.1745-6584.2005.00158.x

Ford, D. C., 1979. A Review of Alpine Karst in the Southern Rocky Mountains of 
Canada. Bulletin of the National Speleological Society, 41: 53-65

Ford, D. C., 1984. Karst Groundwater Activity and Landform Genesis in Modern Permafrost Regions of Canada. In: La Fleur, R. G., ed., Groundwater as a Geomorphic Agent. Allen \& Unwin, London. 340-350

Ford, D. C., 2004. Bear Rock Karst, Canada. In: Gunn, J., ed., Encyclopedia of Caves and Karst Science. Fitzroy Dearborn, New York, London. 137-138

Ford, D. C., Williams, P. W., 2007. Karst Hydrogeology and Geomorphology. John Wiley and Sons, Ltd., Chichester. 562

Gams, I., 1978. The Polje: The Problem of Definition. Zeits. für Geomorphology, 22: 170-181

Ginés, Á., 2009. Karrenfield Landscapes and Karren Landforms. In: Ginés, Á., Knez, M., Slabe, T., et al., eds., Karst Rock Features. Karren Sculpturing. Zalozba ZRC. Institut za Raziskovanje Krasa ZRC SAZU, Postojna-Ljubljana, Carsologica, 9. 13-24

Gómez-Pujol, L., Fornós, J. J., 2009. Coastal Karren in the Belearic Islands. In: Ginés, A., Knez, M., Slabe, T., et al., eds., Karst Rock Features. Karren Sculpturing Zalozba ZRC. Institut za raziskovanje krasa ZRC SAZU, Postojna, Ljubljana. Carsologica, 9. 487-502

Grund, A., 1914. Die Geographische Zyklus im Karst. Gesellschaft für Erdkunde, 52: 621-640

Gvozdetskiy, N. A., 1965. Types of Karst in the U.S.S.R. Separatum, Prob. Speleol. Res., Prague. 47-54

Gvozdetskiy, N. A., 1981. Karst. Izd-vo Miszl, Moscow. 214

Hevesi, A., 1986. Hideg vizek Létrehozta Karsztok Osztályozása (Classification of Cold-Water Karsts). Földrajzi Értesitö, 35: 231-254 (in Hungarian)

Horn, G., 1935. Über Die Bildung von Karsthöhlen Unter Einem Gletscher. Norsk Geografisk Tidsskrift-Norwegian Journal of Geography, 5(7/8): 494-498. https://doi.org/10.1080/00291953508542704

Jakucs, L., 1977. Morphogenetics of Karst Regions. Adam Hilgar, Bristol. 284 Jennings, J. N., 1964. Geomorphology of Punchbowl and Signature Caves, Wee Jasper, New South Wales. Helectite, 2: 57-80

Jennings, J. N., 1985. Karst Geomorphology. Basil Blackwell, New York. 293

Johnson, K. S., Collins, E. W., Seni, S. J., 2003. Sinkholes and Land Subsidence due to Salt Dissolution near Wink, West Texas and Other Sites in Western Texas and New Mexico. Oklahoma Geological Survey Circular, 109: 163-195

Klimchouk, A., 2004. Evaporite Karst. In: Gunn, J., ed., Encyclopedia of Caves and Karst Science. Fitzroy Dearborn, New York, London. 343-347

Klimchouk, A., Andrejchuk, V., 2003. Karst Breakdown Mechanisms from Observations in the Gypsum Caves of the Western Ukraine: Implications for Subsidence Hazard Assessment. International Journal of Speleology, 31(1/4): 55-88. https://doi.org/10.5038/1827-806x.31.1.4

Knez, M., Slabe, T., 2009. Lithological Characteristics Shape, and Rock Relief of the Lunan Stone Forests. In: Ginés, Á., Knez, M., Slabe, T., et al., eds., Karst Rock Features, Karren Sculpturing Zalozba ZRC. Institut za raziskovanje krasa ZRC SAZU, Postojna. Carsologica, 9: 439-452

Komatina, M., 1982. A Fejlődés Feltételei és a Karsztos Területek Felosztása (Conditions of Evolution and Classification of Karst Areas). In: Burger, A., Dubertret, L., eds., Karsztterületek Hidrogeológiája. MKBT, Budapest. 23-35 (in Hungarian)

Korzhuev, S. S., 1961. Merzlotnij Karszt Szrednego Prilenja i Nekotorije Oszobennoszti Jego Projavlenija. In: Sokolov, N. I., Gvozdetskiy, N. A., Balashov, L. S., eds., Regionalnoje Karsztovedenije. Izdatelsztvo AN SzSzSzR, Moscow. 207-220

Kósa, A., 1981. A Bir Al Ghanam-i Sivatagi Gipsz-Karszt (Desert Gypsum Karst of Bir Al Ghanam). Karszt és Barlang, I/II: 21-26 (in Hungarian)

Kovács, J., Müller, P., 1980. A Budai-Hegyek Hévizes Tevékenységének Kialakulása és Nyomai (Origin and Traces of Hydrothermal Activities in the Buda Range). Karszt és Barlang, II: 93-98 (in Hungarian)

Kunaver, J., 1983. Geomorphology of the Kanin Mountains with Special Regard to the Glaciokarst. Geografski Zbornik, XXII(1): 201-343

Lauriol, B., Gray, J. T., 2006. Drainage Karstique en Milieu de Pergélisol: Le Cas de l'ile d'Akpatok, T.N.O. Canada. Permafrost and Periglacial Processes, 1(2): 129-144. https://doi.org/10.1002/ppp.3430010205

Lauritzen, S. E., 1984. A Symposium: Arctic and Alpine Karst. Norsk Geografisk Tidsskrift-Norwegian Journal of Geography, 38(3/4): 139-143. https://doi.org/10.1080/00291958408552117

Leél-Össy, S., 1959. Magyarország Karsztvidékei (Karst Regions of Hungary). Karszt és Barlangkutatás, I: 79-88 (in Hungarian)

Leél-Össy, S., 1960. Magyarország Karsztvidékei (Karst Regions of Hungary). Földrajzi Értesitő, 9(1-4): 490-495 (in Hungarian)

Leél-Össy, S., 2017. Caves of Buda Thermal Karst. In: Klimchouk, A., Palmer, N., De Waele, A., et al., eds., Hypogene Karst Regions and Caves of the World. Springer International Publishing. 279-298

Liu, H., Tan, X. C., Li, L., et al., 2019. Eogenetic Karst in Interbedded Carbonates and Evaporites and Its Impact on Hydrocarbon Reservoir: A New Case from Middle Triassic Leikoupo Formation in Sichuan Basin, Southwest China. Journal of Earth Science, 30(5): 908-923. https://doi.org/10.1007/s12583-019-0888-7

Lu, Y., Cooper, A. H., 1997. Gypsum Karst Geohazards in China. In: Beck, B. F., Stephenson, J. B., eds., Engineering Geology and Hydrogeology of Karst Terrains. Balkema, Rotterdam. 117-126

Lundberg, 2009. Coastal Karren. In: Ginés, A., Knez, M., Slabe, T., et al., eds., Karst Rock Features. Karren Sculpturing Zalozba ZRC. Institut za Raziskovanje Krasa ZRC SAZU, Postojna, Ljubljana. Carsologica, 9. 249-264

Macaluso, T., Sauro, U., 1996. The Karren in Evaporitic Rocks: A Proposal of Classification. In: Fornos, J. J., Ginés, A., eds., Karren Landforms, Universitat de les Illes Balears, Palma de Mallorca. 277-293

Madonia, G., Sauro, U., 2009. The Karren Landscapes in the Evaporitic Rocks of Sicily. In: Ginés, Á., Knez, M., Slabe, T., et al., eds., Karst Rock Features, Karren Sculpturing Zalozba ZRC. Institut za Raziskovanje Krasa ZRC SAZU, Postojna. Carsologica, 9. 525-533

Martinez, J., Johnson, K., Neal, J., 1998. Sinkholes in Evaporite Rocks. American Scientist, 86(1): 38-51. https://doi.org/10.1511/1998.1.38

McLean, R. F., 1974. Geologic Significance of Bioerosion of Beachrock. In: Proceedings of the 2nd International Coral Reef Symposium. Great Barrier Reef Committee, Brisbane. 401-408

Milanovič, P., Maksimovich, N., Meshcheriakova, O., 2019. Dams and Reservoirs in Evaporites. Springer, Cham. 157

Móga, J., Strat, D., Mari, L., et al., 2018a. A Meledic-Fennsík (Románia) Sókarsztos Felszínformáinak Vizsgálata (Investigation of the Saltkarst Landforms of the Meledic Plateau, Romania). Karsztfejlödés, XXIII: 113-139 (in Hungarian)

Móga, J., Strat, D., Szabó, J., et al., 2018b. A Meledic-Fennsík (Románia) Sódolináinak Genetikai, Morfológiai, és Morfometriai Vizsgálata (Investigation of the Saltdolines of the Meledic Plateau, Romania). Karsztfejlödés, XXIII: 141-162 (in Hungarian)

Móga, J., Szabó, J., Gönczy, S., et al., 2017. Az Aknaszlatinai-Sókarszt Dinamikusan Változó Felszínformáinak Vizsgálata Terepi és gis mó Dszerekkel (The Study of the Dynamically Changing Landforms of Aknaszlatina Salt Karst by Field and GIS Methods). Karsztfejlödés, XXII: 139-161 (in Hungarian)

Pollard, W., Omelon, C., Andersen, D., et al., 1999. Perennial Spring Occurrence in the Expedition Fiord Area of Western Axel Heiberg Island, Canadian High Arctic. Canadian Journal of Earth Sciences, 36(1): 105-120. https://doi.org/10.1139/e98-097 
Pulina, M., 2005. Le Karst et les Phenomenes Karstiques Similaires des Regions Froides. In: Salomon, J. N., Pulina, M., eds., Les Karsts des Regions Climatiques Extremes. Karstologia Mémoires, 14: 11-100

Quinlan, J. F., 1978. Types of Karst, with Emphasis on Cover Beds in Their Classification and Development: [Dissertation]. University of Texas Austin, Austin

Quinlan, J. F., Smith, A. R., Johnson, K. S., 1986. Gypsum Karst and Salt Karst of the United States of America. Le Grotte d'Italia, 4(13): 73-92

Rónaki, L., 1970. Karsztnevezéktani Javaslat (Karst Nomenclature Suggestion). Karszt és Barlang, II: 77-84 (in Hungarian)

Sauro, U., 2012. Closed Depressions in Karst Areas. In: White, W. B., Culver, D. C., eds., Encyclopedia of Caves. Elsevier, Amsterdam. 140-155

Siever, R., 1962. Silica Solubility, $0^{\circ}-200^{\circ}$ C, and the Diagenesis of Siliceous Sediments. The Journal of Geology, 70(2): 127-150. https://doi.org/10.1086/626804

Siffert, B., 1962. Quelques Reactions de la Silice en Solution: La Formation des Argiles. Mémoires du Service de la Carte Géologique d'Alsace et de Lorraine, 21: 50-75

Skoglund, R. Ø., Lauritzen, S. E., Gabrovšek, F., 2010. The Impact of Glacier Ice-Contact and Subglacial Hydrochemistry on Evolution of Maze Caves: A Modelling Approach. Journal of Hydrology, 388(1/2): 157-172. https://doi.org/10.1016/j.jhydrol.2010.04.037

Smart, C., 2004. Glacierized and Glaciated Karst. In: Gunn, J., ed., Encyclopedia of Caves and Karst Science. Fitzroy-Dearborn, New York, London. 389-390

Smart, P. I., 1986. Origin and Development of Glacio-Karst Closed Depressions in the Picos de Europa, Spain. Zeitschrift für Geomorphologie, 32(4): 423-443

Sweeting, M. M., 1973. Karst Landforms. Columbia University Press, New York. 362

Szablyár, P., 1981. Az Umm Al Masabih-Barlang (Líbia) Morfogenetikája (Morphogenetics of Umm Al Masabih Cave). Karszt és Barlang, I/II: 27-34 (in Hungarian)

Trudgill, S. T., 1985. Limestone Geomorphology. Longman, New York. 196

Van Everdingen, R. O., 1981. Morphology, Hydrology and Hydrochemistry of Karst in Permafrost near Great Bear Lake, Northwest Territories, Paper 11. National Hydrological Research Institute of Canada, Saskatoon. 53

Venkovits, I., 1959. Karsztvíz Nevezéktani vita (Karstwater Nomenclature Debate). Karszt és Barlangkutatás, I: 25-28 (in Hungarian)

Veress, M., 2000. Covered Karst Evolution Northern Bakony Mountains, W-Hungary. A Bakony Természettud. Kut. Eredményei 23, Bakonyi Természettudományi Múzeum, Zirc. 167

Veress, M., 2010. Karst Environments. Karren Formation in High Mountains. Springer, Dordrecht, Heidelberg, London, New York. 230

Veress, M., 2016. Covered Karst. Springer, Berlin, Heidelberg, New York. 536. https://doi.org/10.1007/978-94-017-7518-2

Veress, M., 2017. Solution Doline Development on Glaciokarst in Alpine and Dinaric Areas. Earth-Science Reviews, 173: 31-48. https://doi.org/10.1016/j.earscirev.2017.08.006

Veress, M., 2019. The Karren and Karren Formation of Bare Slopes. Earth-Science Reviews, 188: 272-290. https://doi.org/10.1016/j.earscirev.2018.11.006

Veress, M., Lóczy, D., Zentai, Z., et al., 2008. The Origin of the Bemaraha Tsingy (Madagascar). International Journal of Speleology, 37(2): 131-142. https://doi.org/10.5038/1827-806x.37.2.6

Veress, M., Puskás, J., Zentai, Z., et al., 2011. Development of Karren Formation on the Saltic Hill of Praid (Transylvanian Basin, Romania). Carpathian Journal of Earth and Environmental Sciences, 6(2): 183-194

Veress, M., Telbisz, T., Tóth, G., et al., 2019. Glaciokarst. Springer Geography, Cham. 516. https://doi.org/10.1007/978-3-319-97292-3

Veress, M., Tóth, G., 2015. Káli Basin: Pseudokarren on Sandstone. In: Lóczy, D., ed., Landscapes and Landforms of Hungary. Springer, Cham Heidelberg, New York, Dordrecht, London. 79-87. https://doi.org/10.1007/973-3-319-08957-3

Veress, M., Vetési-Foith, S., 2019. The Distribution of Surface Karst Features in the Bakony Region (Transdanubian Mountains, Hungary). Journal of Geological Research, 1(1): 21-25. https://doi.org/10.30564/jgr.v1i1.622

Veress, M., Zentai, Z., Péntek, K., et al., 2014. A Léna Pillérei (The Lena Pillars). Földrajzi Közlemények, 138(1): 17-36 (in Hungarian)

Waele, J. D., Piccini, L., Columbu, A., et al., 2017. Evaporite Karst in Italy: A Review. International Journal of Speleology, 46(2): 137-168

Waltham, A. C., Fookes, P. G., 2003. Engineering Classification of Karst Ground Conditions. Quarterly Journal of Engineering Geology and Hydrogeology, 36(2): 101-118. https://doi.org/10.1144/1470-9236/2002-33

Waltham, T., 2008. Fengcong, Fenglin, Cone Karst. Cave and Karst Science, 35(3): 77-88

Waltham, T., Bell, F., Culshaw, M., 2005. Sinkholes and Subsidence. Springer, Berlin Heidelberg. 382

White, W. B., 1988. Geomorphology and Hydrology of Karst Terrains. Oxford University Press, New York, Oxford. 464

Williams, P. W., 1966. Limestone Pavements with Special Reference to Western Ireland. Transactions of the Institute of British Geographers, 40: 155-172. https://doi.org/10.2307/621575

Williams, P. W., 1971. Illustrating Morphometric Analysis of Karst with Examples from New Guinea. Zeitschrift für Geomorphologie, 15(1): 40-61

Williams, P. W., 1985. Subcutaneous Hydrology and the Development of Doline and Cockpit Karst. Zeitschrift für Geomorphologie, 29(4): 463-482

Williams, P. W., 2004. Dolines. In: Gunn, J., ed., Encyclopedia of Caves and Karst Science. Fitzroy Dearborn, New York, London. 304-310

Williams, P. W., 2009. Arête and Pinnacle Karst of Mount Kaijende. In: Ginés, Á., Knez, M., Slabe, T., et al., eds., Karst Rock Features. Karren Sculpturing Zalozba ZRC. Institut za Raziskovanje Krasa ZRC SAZU, Postojna. Carsologica, 9. 433-437

Wray, R., 1997. A Global Review of Solutional Weathering Forms on Quartz Sandstones. Earth-Science Reviews, 42(3): 137-160. https://doi.org/10.1016/s0012-8252(96)00056-6 